\title{
SUNDA WIWITAN DI ERA POST-TRUTH: STRATEGI BERTAHAN KOMUNITAS LOKAL DI ERA GLOBALISASI
}

\author{
Hasse Jubba $^{\mathrm{a}, 1,}$, Nispi Amalia Adila ${ }^{\mathrm{b}, 2}$, Herianto $^{\mathrm{c}, 3}$, Trina Septiani ${ }^{\mathrm{d}, 4 *}$ \\ ${ }^{a}$ Universitas Muhammadiyah Yogyakarta, Yogyakarta, 55183, Indonesia \\ ${ }^{b}$ Universitas Gadjah Mada, Yogyakarta, 55281, Indonesia \\ ${ }^{c}$ Universitas Gadjah Mada, Yogyakarta, 55281, Indonesia \\ ${ }^{d}$ Universitas Gadjah Mada, Yogyakarta, 55281, Indonesia \\ ${ }^{1}$ hasse@umy.ac.id *; ${ }^{2}$ nispiamalia99@mail.ugm.ac.id *; ${ }^{3}$ herianto97@mail.ugm.ac.id *; ${ }^{4}$ trina.s@mail.ugm.ac.id*;
}

ARTICLE INFO

Article history:

Received : 2021-08-31

Accepted : 2021-12-24

Keywords:

Sunda Wiwitan

Defense Strategy

Post-Truth

Cireundeu Traditional Village
Revised : 2021-11-01

\section{ABSTRACT}

The existence of the Sunda Wiwitan community in Cireundeu Traditional Village has been faced with the threat of massive technological advances. Massive penetration of technology has caused indigenous people to use and accept technology as a necessity. In line with this, this paper was to explain how the sustainability and survival strategy of Sunda Wiwitan people in post truth era. This paper was based on data collected through direct observation and interviews with five different informants by taking into account the characteristics of each. The result showed that there was a strong influence between technology and the existence of Sunda Wiwitan as indigenous people. Indigenous people were able to adapt to all existing openness. This study confirmed that today's indigenous people still prevented their customs. Therefore, the existence of local communities needed to be guaranteed through various schemes, including supporting regulations that were protective in nature.

\section{ABSTRAK}

Kata kunci:

Sunda Wiwitan

Strategi Bertahan

Post-Truth

Kampung Adat Cireundeu
Keberadaan komunitas Sunda Wiwitan di Kampung Adat Cireundeu dihadapkan pada ancaman atas kemajuan teknologi yang sangat massif. Penetrasi teknologi yang berlangsung secara massif menyebabkan masyarakat adat memanfaatkan dan menerima teknologi sebagai sebuah kebutuhan. Sejalan dengan hal tersebut, tulisan ini bertujuan menjelaskan bagaimana keberlangsungan dan strategi bertahan masyarakat Sunda Wiwitan di era post truth. Tulisan ini didasarkan pada data yang dikumpulkan melalui observasi dan wawancara langsung kepada lima informan yang berbeda dengan memperhatikan karakteristik masing-masing. Hasil penelitian memperlihatkan bahwa terdapat pengaruh kuat antara teknologi dengan keberadaan Sunda Wiwitan sebagai masyarakat adat. Masyarakat adat mampu beradaptasi dengan segala keterbukaan yang ada. Studi ini menegaskan bahwa masyarakat adat saat ini. Oleh karena itu, keberadaan komunitas lokal perlu dijamin keberadaannya melalui berbagai skema termasuk keberpihakan regulasi yang bersifat melindungi. 


\section{Pendahuluan}

Eksistensi Sunda Wiwitan mulai dipertanyakan di era post-truth. Masyarakat penganut Sunda Wiwitan yang berada di Kampung Adat Cireundeu terbuka akan perkembangan zaman, masyarakat adat telah memanfaatkan teknologi, seperti penggunaan smartphone dan televisi. Status Kampung Adat Cireundeu sebagai kampung wisata memberikan ruang akan interaksi dengan dunia luar yang modern. Dalam menghadapi situasi dan kondisi perkembangan zaman (Nurhayanto \& Wildan, 2016) penganut Sunda Wiwitan senantiasa berpegang teguh pada prinsip "ngindung ka waktu mibapa $k a$ jaman" agar kearifan dan ajaran agama Sunda Wiwitan tidak hilang. Ajaran Sunda Wiwitan sendiri menjadikan Piku Tiluh sebagai dasar pijakan kepercayaan yang tersusun dalam Trilogis hubungan Tuhan, manusia, dan alam.

Sejauh ini studi tentang eksistensi Sunda Wiwitan cenderung melihat dua hal. Pertama, status Sunda Wiwitan dalam hal pengakuan pemerintah akan hak sipil (Sabandiah \& Wijaya, 2018) bagi penganut Sunda Wiwitan dalam sudut pandang kesejahteraan sosial (Budijanto, 2016; Dahlan \& Liemanto, 2017; Pamungkas, 2014). Pengakuan hak-hak sipil meliputi 4 aspek, yaitu aspek mental, aspek sosial, aspek spiritual, dan aspek ekonomi (Vonika, 2020). Sebagaimana ditunjukkan bahwa hukum adat Sunda Wiwitan belum sepenuhnya memperoleh legitimasi secara utuh oleh pemerintah, di mana hal tersebut sangat rentan akan lahirnya gesekan dan konflik termasuk konflik kepemilikan lahan yang berkepanjangan (Farakhiyah \& Irfan, 2019). Kedua, jaminan mengenai hak akan kebebasan dalam menjalankan aktivitas spiritual yang dimiliki oleh penganut Sunda Wiwitan di tanah ulayat di mana saat ini telah menjadi kawasan wisata yang ditetapkan oleh Negara (Sukirno, 2018), kawasan wisata dapat menjadi jalan tengah untuk menguatkan identitas mereka (Nusanto \& Widiyanto, 2021; Salim, 2016). Akan tetapi, di sisi lain hal itu bisa juga menjadi bumerang akan keberlangsungan adat (Dudi, 2018).
Dari beberapa studi yang ada, studi yang menyoroti tentang bagaimana kemampuan Sunda Wiwitan bertahan di tengah perkembangan (modernisasi) masih jarang dilakukan. Studi ini akan menitik beratkan pada kekosongan studi-studi yang telah ada. Sejalan dengan itu, tiga pertanyaan yang akan dijawab dalam tulisan ini, yakni: Bagaimana kondisi keberadaan Sunda Wiwitan saat ini? Apakah dengan membuka diri dengan dunia luar dianggap sebagai ancaman atas masa depan komunitas Sunda Wiwitan? Bagaimana masa depan Sunda Wiwitan?. Jawaban atas ketiga pertanyaan di atas memungkinkan untuk dipahaminya keberlangsungan Sunda Wiwitan sebagai agama lokal yang menjadi bagian dari kekayaan Indonesia yang juga memiliki kontribusi bagi terbangunnya hubungan sosial yang lebih harmonis.

Tulisan ini didasarkan pada asumsi bahwa Sunda Wiwitan sebagai komunitas lokal dan kampungnya dinyatakan sebagai daerah wisata yang harus mengalami penyesuaian/adaptasi dengan dunia luar dalam hubungannya dengan upaya mempertahankan diri. Ada tiga cara yang dilakukan untuk menjamin keberlangsungannya di masa mendatang. Pertama, berpegang teguh pada ajaran leluhur. Kedua, terbuka dengan modernisasi. Ketiga, terbuka dengan masyarakat umum atau tidak menutup diri. Ketiga cara inilah yang akan diulas secara rinci pada diskusi artikel ini.

\section{Tinjauan Pustaka}

\section{a. Era Post-Truth}

Berdasarkan laporan Washington Times dari Oxford University Time Magazine (BBC pada tahun 2016, salah satu kamus online terkemuka dunia yang dibuat oleh Oxford University, Oxford Dictionary menobatkan truth sebagai kata terbaik tahun ini. Jika 2016 menjadi tahun kecelakaan yang kontroversial, maka ini seharusnya tidak mengejutkan banyak orang. Panorama politik dan sosial dalam kurun waktu ke depan akan ditandai dengan iklim post-riil ini, dengan objektivitas dan rasionalitas yang mengalah pada emosi atau keinginan untuk mengukuhkan iman. 
Jika dicek dari samping, kata kebenaran (truth) secara etimologi, berasal dari kosakata bahasa Inggris. Dalam Kamus Oxford, poststatement mengacu pada fakta (setelah), dan kebenaran mengacu pada kualitas atau keadaan kebenaran (kualitas atau berada dalam keadaan benar). Truth adalah kata benda dari kata sifat true. Oleh karena itu, post truth mengacu pada post true. Disebut era post-truth karena pada periode ini penggunaan akal berdasarkan fakta dan observasi fakta sebagai dasar pengukuran objektivitas tampaknya tidak relevan untuk mempengaruhi opini, pemikiran, dan perilaku masyarakat. Selama periode ini, orang-orang memprioritaskan cara-cara yang sensasional dan bergerak untuk mempengaruhi emosional publik.

Saat ini, Publik lebih tertarik pada kemeriahan berita, apakah mereka lebih patriarkal dan hal-hal yang menyentuh emosi, seperti membuat Anda merasa bahagia, melahirkan kesedihan, kekecewaan, amarah, dan sikap lainnya. Publik menjadi lebih sensitif ketika mereka sedikit tergerak. Steve Tesich adalah yang pertama menggunakan istilah "pasca-nyata". Istilah ini dalam istilah Government of Lies pada Jurnal Nasional yang diterbitkan pada tanggal 6 Januari 1992. Dia menggunakan Insiden Watergate Amerika (1972-1974) dan Perang Teluk Persia sebagai latar belakang untuk menunjukkan kondisi sosial. Di era yang tampaknya "nyaman" itu, hidup di dunia yang penuh kebohongan. terlihat bahwa publik tidak terlalu peduli dengan kebenaran, tetapi bersikeras pada pilihan bebas untuk hidup di ruang pasca-kebenaran.

Di Indonesia, era post truth sendiri diartikan dalam makna bahwa post truth adalah era di mana sesuatu yang bernama "kebenaran" seakan bebas diklaim kapan pun dan oleh siapa pun, orang tidak lagi peduli pada realitas kebenaran yang sesungguhnya, tetapi justru lari kepada informasi bukan informasi kebenaran sebagaimana yang dikehendakinya, melainkan justru bisa jadi sebaliknya. Apalagi diera pasca kebenaran (post-truth) seperti sekarang ini, di mana ilmu pengetahuan dan teknologi berkembang begitu pesat dan secara otomatis pola dan gaya hidup manusia pun berubah mengikuti derap langkah zamannya. Pada penelitian ini kami mencoba mempopulerkan agama Sunda
Wiwitan dengan digitalisasi yakni peliputan yang disebarkan di aplikasi youtube, dari sana dapat terlihat bahwa masyarakat Sunda Wiwitan tidak menolak perkembangan zaman dan bahkan ikut mendukung. Di mana hal seperti ini belum ada di penelitian sebelumnya.

\section{b. Survival Strategy}

Strategi bertahan hidup dapat diartikan sebagai metode yang digunakan oleh seseorang atau sekelompok orang untuk mempertahankan eksistensi diri yang berharga atau baik materi maupun non materi. Strategi menghilangkan ancaman yang sewaktu-waktu dapat merusak nilai, nilai-nilai tersebut telah menjadi kearifan masyarakat. Oleh karena itu, pandangan yang beragam tentang praktik keagamaan lokal harus bersumber dari penelitian empiris komprehensif yang sarat informasi, termasuk analisis interaksi antara berbagai struktur sosial yang ada dalam konteks lokal, karena ruang selalu tersedia. Interaksi struktural akan sampai batas tertentu, mengarah pada pemahaman tentang hubungan yang bukannya tanpa fungsi struktural sosial, termasuk kelas sosial, struktur elite dalam hal ini, pemerintah atau aktor biasa, dan lahirnya yayasan atau masyarakat. Suatu kelompok memiliki berbagai cara untuk mempertahankan keberadaan mereka yakni berupa negosiasi dan resistensi (Fringka, 2016; Muhammad, 2017; Wahyuni, 2019), karena dalam proses dan tindak yang dilakukan untuk menjaga eksistensi suatu kelompok memiliki ruang untuk melahirkan resistensi (Gunawiayu, Purnomowulan, \& Wardiani, 2019; Ismail, 2015).

Sekuler, agama besar dan agama minoritas, meminjam terminologi Durkheim; agama profetik dan agama non-profetik serta lainnya merupakan tipologi terkait dengan agama yang jamak digunakan saat ini. Konstruksi teologis agama sering kali menimbulkan konsensus kolektif yang mengaitkan alam spiritual manusia dengan hukum sosial, ruang dan latar belakang kedua hukum itu berbeda, dan hukum yang bersesuaian juga berbeda. Membangkitkan pendapat yang berbeda. Misalnya, jika kita menerima kepercayaan agama dalam skala sosiolog, Durkheim akan menganggap agama sebagai sistem kepercayaan dan praktik yang 
berkaitan dengan hal-hal sakral, yaitu, kepercayaan dan praktik yang mempengaruhi moral komunitas pemeluknya. Moralitas publik semacam ini menunjukkan bahwa agama adalah hubungan antara sesamanya atau kesatuan sosial yang mempersatukan masyarakat dalam ikatan moral kolektif. Orang-orang di sini berada pada posisi pasif yang didominasi oleh sistem moral, yang menjadikan mereka sebagai bagian integral dari sistem dan mekanisme sosial.

Dalam konsep solidaritas Durkheim ada dua bentuk, yaitu solidaritas mekanik dan solidaritas organik. Penduduk pedesaan termasuk dalam solidaritas mekanis. Maksudnya adalah mereka masih percaya pada hubungan nyata. Suatu hubungan di mana tidak semuanya tergantung semata-mata pada nilai keuntungan, tetapi juga ikatan yang kuat dengan hukum-hukum sosial yang berlaku dalam suatu kelompok karena adanya perasaan memiliki teman sebaya terhadap komunitas mekanis (Rahmawati dkk., 2019). Dalam hal ini, Durkheim lebih jauh menekankan bahwa keyakinan agama tidak lebih dari cerminan masyarakat itu sendiri, ritual keagamaannya memperkuat sosialisme kelompok dan menegaskan keyakinan pada tatanan moral. Oleh karena itu, Durkheim tidak mengatakan bahwa agama adalah fenomena sosial, tetapi masyarakat adalah fenomena religius. Berdasarkan pernyataan tersebut dapat dijelaskan bahwa agama mengintegrasikan sistem sosial yang merupakan aksioma struktur fungsional dasar. Dalam bahasa lain, Agama sebagai rangkaian simbol yang membangkitkan kekaguman, serta mengacu pada berbagai ritual yang dilakukan oleh komunitas pemuja. Bentuk agama atau kepercayaan ini nyata dan ada di Indonesia. Oleh karena itu, yang terjadi dalam ritual agama tradisional (termasuk kesamaan agama masyarakat LOM) adalah entitas yang memiliki landasan teologis, antropologi, bahkan historis dan esensinya tidak sama dengan apa yang disebut pemerintah sebagai "religius" keyakinan perbedaan agama resmi.

\section{c. Sunda Wiwitan Sebagai Komunitas Lokal}

Masyarakat adat yang menjaga adat istiadat dan nilai-nilai tradisionalnya disebut kearifan lokal, mereka tetap dapat bertahan di era mobilisasi yang cepat dan pesat, dan hal ini tidak ketinggalan zaman atau terbelakang bagi kearifan lokal. Adapun ciri-ciri kearifan lokal adalah mampu bertahan terhadap budaya luar, memiliki kemampuan mengakomodasi unsur-unsur budaya luar, mempunyai kemampuan mengintegrasikan unsur budaya luar ke dalam budaya asli, mempunyai kemampuan mengendalikan, dan mampu memberi arah pada perkembangan budaya. Partisipasinya dalam berbagai bentuk kehidupan adalah hasil dari pemeliharaan adat istiadatnya dalam jangka panjang. Desa adat yang bisa bertahan adalah masyarakat yang bisa menjaga adat istiadatnya. Namun, ini tidak berarti mereka tertutup atau terisolasi dari dunia luar. Karena pengaruh masyarakat, mereka tetap bersikukuh pada apa yang menurut mereka lebih berpengaruh daripada perubahan di luar lingkungan. Salah satunya adalah desa adat Cireundeu yang masih memegang teguh tradisi Masyarakat. Orang berpikir bahwa dunia luar berbeda dengan cara hidup kebanyakan orang.

Proses perubahan nilai-nilai kearifan lokal yang dilakukan oleh masyarakat adat Cireundeu diprakarsai oleh nenek moyang atau mantan sesepuh yang mencari kebenaran spiritual. Proses perubahan yang terjadi pada nilai-nilai kearifan lokal lingkungan sosial Cireundeu sesuai dengan teori tindakan Parson, yaitu Pertama, Tindakan mengisyaratkan adanya pelaku, seorang "aktor", yang menjadi aktor dalam hal ini adalah budayawan adat Cireundeu. Kedua, Guna keperluan definisi tindakan harus ada "pencapaian", suatu keadaan masa depan yang akan dikejar oleh tindakan tersebut, dalam hal ini tujuan yang ingin dicapai oleh budayawan adat Cireundeu yakni pemaknaan agama lokal Sunda yaitu Sunda Wiwitan sebagai identitas budaya setelah leluhur mereka yakni Kyai Haji Ali mendapatkan kebenaran spiritual dari hasil pengembaraannya. Selain pengertian agama yang dijadikan sebagai pengertian budaya, "pencapaian" masyarakat adat Cireundeu yang ingin dicapai adalah membuka diri untuk menikah dengan penganut agama lain. Ketiga, Tindakan harus dimulai dalam suatu "keadaan" yang kecenderungankecenderungan perkembangannya berbeda dalam satu (atau lebih) aspek penting keadaan yang akan dikejar oleh tindakan itu, yaitu tujuan. "Keadaan" dalam hal ini adalah 
masyarakat adat Cireundeu bersikap terbuka pada perubahan namun perubahan tersebut mengkondisikan mereka dalam situasi bahwa Sunda Wiwitan tidak dikelompokkan sebagai suatu agama oleh pemerintah.

Komunitas adat Cireundeu mewarisi nilai-nilai kearifan lokal dan mengalami proses transformasi alamiah. Selain itu, mereka membutuhkan pendidikan dan informasi agar tidak ketinggalan zaman, karena pepatah Daren mengatakan bahwa mereka selalu berusaha untuk "ngindung $k a$ waktu, mibapa $k a$ jaman" (harus menyesuaikan dengan perubahan zaman). Hal ini terjadi setelah proses transformasi masyarakat adat Cireundeu, penganut kepercayaan Sunda Wiwitan, yang tidak sebatas menikah dengan penganut agama lain. Ini untuk memastikan bahwa mereka akan mendapatkan hak sipil di masa depan. Sebagaimana amanat penegak hak-hak sipil dalam undang-undang tentang hak asasi manusia.

\section{Metodologi Penelitian}

Penelitian ini dilakukan di Kampung Adat Cireundeu, Kelurahan Leuwigajah, Kecamatan Cimahi Selatan, Kota Cimahi, bersandar pada data primer dan sekunder. Data primer diperoleh dari studi lapangan untuk mengamati langsung dan dari pemetaan aspek-aspek penelitian. Data yang dibutuhkan terdiri dari data wujud, faktor dan implikasi. Wujud eksistensi menyangkut bagaimana kondisi Sunda Wiwitan saat ini. Persoalanpersoalan apa yang dihadapi oleh penganut Sunda Wiwitan di era post-truth. Data menyangkut bagaimana masa depan Sunda Wiwitan sebagai agama lokal. Tema ini dipilih didasarkan atas dua pertimbangan. Pertama, persoalan Sunda Wiwitan sebagai agama lokal di era post-truth merupakan topik sentral yang belum banyak diperhatikan dalam studi-studi terdahulu. Kedua, keberlangsungan Sunda Wiwitan khususnya sebagai objek wisata menjelaskan tentang adanya hubungan kearifan lokal dan era globalisasi dengan kemajuan teknologi. Kedua alasan dipilihnya isu eksistensi Sunda Wiwitan sebagai pokok pembahasan tulisan diharapkan memberikan pemahaman yang komprehensif dan wawasan bagi pemecahan masalah.
Proses penelitian berlangsung satu bulan yang dimulai dari desk-review, observasi lapangan, dan wawancara. Sebelum penelitian lapangan dilakukan dikumpulkan berbagai bahan sekunder, termasuk berita online, untuk melihat kondisi yang terjadi pada tataran teks. Observasi dilakukan di Kampung Adat Cireundeu dengan melakukan pengamatan secara langsung. Wawancara berlangsung dalam tiga kategori kelas sosial untuk tujuan perbandingan. Wawancara dilakukan di tempat masing-masing informan setelah terlebih dahulu mendapatkan persetujuan. Empat orang dipilih sebagai informan yang terlibat dalam sesi wawancara yang bertujuan untuk menggali informasi lebih aktual. Penelitian ini melibatkan lima informan dalam pengumpulan data, yaitu: informan yang terdiri dari kaum elite dalam masyarakat seperti tokoh agama atau kaum intelektual Sunda Wiwitan, Pemuda masyarakat adat Sunda Wiwitan dan masyarakat umum serta pemerintah daerah di Cireundeu. Ketiga pihak dilibatkan untuk menguji bagaimana kelas sosial memiliki signifikansi dalam interpretasi dan apakah kapasitas intelektual memberikan pengaruh pada pandangan dan sikap yang diberikan.

Analisis data dilakukan dalam dua bentuk. Pertama, pengolahan data dimulai dari reduksi data pengamatan dan wawancara, penampilan data yang dilakukan dalam bentuk ringkasan dan sinopsis berdasarkan tematema temuan lapangan, dan verifikasi data untuk proses penyimpulan. Kedua, analisis yang digunakan mengikuti teknik interpretasi yang dimulai dari restatement atas data yang ditemukan baik dari observasi maupun wawancara, diikuti dengan description untuk menemukan pola atau kecenderungan dari data, diakhiri dengan interpretation untuk mengungkapkan makna dari data yang telah dikumpulkan.

\section{Hasil dan Diskusi}

\section{a. Sekilas Tentang Sunda Wiwitan di Kampung Adat Cireundeu}

Cireundeu berasal dari kata " $c i$ " dan "reundeu". Ci adalah cai atau air dan rendeu diambil dari nama pohon reundeu yang merupakan pohon untuk bahan obat herbal. Kampung Adat Cireundeu terletak di Kelurahan Leuwigajah, Kecamatan Cimahi 
Selatan, Kota Cimahi. Kampung Adat Cireundeu sendiri memiliki luas 64 ha terdiri dari 60 ha untuk pertanian dan 4 ha untuk pemukiman yang dihuni oleh kurang lebih 367 kepala keluarga atau kurang lebih 1.200 jiwa. Terdiri dari 550 orang perempuan dan 650 orang laki-laki. Kondisi sosial masyarakat di kampung Cireundeu memiliki keadaan sosial yang terbuka dengan masyarakat luar. Sebagian besar penduduknya memeluk dan memegang teguh kepercayaan Sunda Wiwitan hingga saat ini. Mereka masih konsisten dalam menjalankan ajaran kepercayaan serta terus melestarikan budaya dan adat istiadat yang telah turun-temurun diwarisi dari nenek moyangnya (Risyadah, 2021).

Masyarakat adat Cireundeu sangat memegang teguh kepercayaannya, kebudayaan serta adat istiadat. Mereka memiliki prinsip "ngindung ka waktu, mibapa ka jaman" arti kata dari "ngindung $k a$ waktu" ialah kita sebagai warga kampung adat memiliki cara, ciri dan keyakinan masing-masing. Adapun "mibapa ka jaman" memiliki arti masyarakat Kampung Adat Cireundeu tidak melawan akan perubahan zaman akan tetapi mengikutinya seperti adanya teknologi, televisi, alat komunikasi berupa handphone, dan penerangan. Masyarakat ini punya konsep kampung adat yang selalu diingat sejak zaman dulu, yaitu suatu daerah itu terbagi menjadi tiga bagian, yaitu (Risyadah, 2021):

1. Leuweung Larangan (hutan terlarang), yaitu hutan yang tidak boleh ditebang pepohonannya karena bertujuan sebagai penyimpanan air untuk masyarakat adat Cireundeu khususnya.

2. Leuweung Tutupan (hutan reboisasi), yaitu hutan yang digunakan untuk reboisasi, hutan tersebut dapat dipergunakan pepohonannya namun masyarakat harus menanam kembali dengan pohon yang baru. Luasnya mencapai 2 hingga 3 hektar.

3. Leuweung Baladahan (hutan pertanian), yaitu hutan yang dapat digunakan untuk berkebun masyarakat adat Cireundeu. Biasanya ditanami oleh jagung, kacang tanah, singkong atau ketela dan umbiumbian.
Lima kalimat yang mereka pegang teguh, yakni "teu boga sawah asal boga pare, teu boga pare asal boga beas, teu boga beas asal bisa nyangu, teu nyangu asal dahar, teu dahar asal kuat" yang artinya "tidak punya sawah asal punya beras, tidak punya beras asal dapat menanak nasi, tidak punya nasi asal makan, tidak makan asal kuat". Kalimat ini seolah merangkum sejarah konsumsi rasi alias beras singkong di Desa Cireundeu. Hal tersebut berkaitan pula dengan tradisi nenek moyang mereka yang kerap berpuasa mengonsumsi beras selama waktu tertentu. Tujuan puasa tersebut adalah mendapat kemerdekaan lahir batin. Ritual yang juga sekaligus menguji keimanan seseorang dan pengingat akan kekuatan Tuhan Yang Maha Esa.

Dalam hal penyediaan bahan makanan seperti rasi dan sebagainya, masyarakat melakukan pengelolaan secara mandiri yang merupakan kelanjutan dari para leluhurnya. Pengolahan singkong menjadi nasi telah dilakukan masyarakat Kampung Adat Cireundeu selama kurang lebih 85 tahun dan hal tersebut membuat mereka mandiri soal pangan. Konsistensi masyarakat adat yang mengonsumsi rasi sebagai makanan pokok membuat masyarakat adat tidak pernah mengonsumsi beras. Hal ini bukan berarti masyarakat adat mengharamkan beras dari padi, namun melestarikan dan mengikuti pesan sesepuh. Rasa kenyang dari konsumsi ketela lebih lama dibandingkan dengan padi. Sehingga masyarakat adat cukup makan dua kali sehari. Kehidupan di Kampung Cireundeu bisa dibilang tak terpengaruh gejolak ekonomi-sosial, terutama soal fluktuasi harga beras.

Pada aspek pemukiman, pola pemukiman di kampung Cireundeu memiliki pintu samping yang harus menghadap ke arah timur. Bertujuan agar masuknya cahaya matahari ke bumi. Kehidupan antar masyarakat hidup dengan semangat gotong-royong. Kampung Cireundeu didominasi masyarakat Muslim, namun keberadaan masyarakat adat menjadikan kampung banyak dikunjungi dan dijadikan tempat wisata, penelitian, acara adat, bahkan acara-acara lain yang bekerja sama dengan berbagai pihak. Meskipun demikian, tradisi adat tetap dilaksanakan dengan tetap memerhatikan protokol kesehatan. Sebagaimana yang diutarakan oleh salah satu masyarakat: 
"Perayaan adat tetap dilakukan begitu pun dengan adat pernikahan, namun selama pandemi belum ada masyarakat adat yang melaksanakan adat pernikahan, bukan akibat dari kondisi pandemi melainkan memang belum ada saja" (KY, 2021).

Sunda Wiwitan di Kampung Adat Cireundeu merupakan gambaran masyarakat agama lokal yang masih memegang teguh tradisi yang diturunkan oleh leluhur serta hidup berdampingan harmonis dengan masyarakat lain yang berbeda kepercayaan. Selain itu, dalam keadaan apa pun, masyarakat adat tetap menjalankan tradisinya dengan tetap mengindahkan peraturan dari pemerintah.

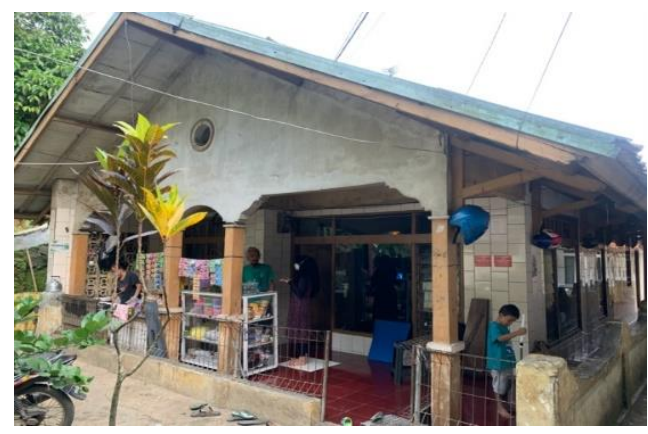

Gambar 1. Rumah Pemukiman

Kehidupan yang harmonis dan saling gotong royong tergambar dalam setiap kegiatan seperti saat kelahiran yang saling membantu dalam menyediakan kendaraan. Saat ada keluarga warga yang meninggal, mereka saling membantu menggali tanah. Namun masyarakat yang berbeda keyakinan tak ikut serta dalam ritual pemakaman. Sedangkan dalam perkawinan, masyarakat adat dan agama atau kepercayaan lain saling mengucapkan permisi dan mengundang satu sama lain. Namun kebiasaan masyarakat datang sehari sebelum acara perkawinan digelar. Sehingga saat hari perkawinan, undangan yang datang adalah keluarga, saudara, teman dan lainnya. Di masa pandemi Covid-19, Kampung Adat Cireundeu tetap beroperasi untuk menerima kunjungan dari dalam kota maupun luar kota. Namun, aktivitasnya masih dibatasi.

\section{b. Tantangan Sunda Wiwitan di Era Post- Truth}

Sebagai komunitas lokal yang terintegrasi dalam sebuah perkampungan adat, Sunda Wiwitan dihadapkan oleh berbagai tantangan.
Masyarakat adat sebagai perwujudan Sunda Wiwitan tentunya kemajuan teknologi di era post truth bagi mereka sulit untuk dibendung. Status kampung mereka sebagai kampung wisata membuat teknologi dan dunia luar menjadi hal yang lumrah. Kelumrahan itu menjadi tantangan tersendiri bagi mereka. Sebagaimana yang diutarakan oleh salah seorang tokoh adat bahwa:

"Kehadiran handphone membuat anakanak di masyarakat adat jadi tidak teratur dan kadang saya juga melakukan tindakan tegas karena dirasa terlalu berlebih walau karena memang kegunaan handphone sendiri sudah menjadi kebutuhan dimasa pandemi saat ini" (KY, 2021).

Penggunaan smartphone pada dasarnya memberikan manfaat kepada penggunanya. Namun, di sisi lain memberikan dampak negatif, salah satunya mengurangi kontak sosial, kepekaan sosial pada keadaan lingkungan dan berdampak pada penurunan kualitas dan kuantitas interaksi tatap muka (Retalia, 2020), padahal hubungan sosial mampu menjaga harmonisasi ditengah masyarakat (Santi, 2021). Dalam riset dilakukan oleh Fajarini mengungkap bahwa kehadiran teknologi perlahan memberikan pengaruh yang menyebabkan terkikisnya kearifan lokal di Kampung Cirendeu khususnya pada generasi muda (Fajarini, 2021). Hal senada disampaikan oleh salah satu pemuda Sunda Wiwitan bahwa muncul ketakutan jika generasi muda tidak mampu menjaga atau mempertahankan budaya serta kearifan lokal Sunda Wiwitan:

"Kesulitan mengumpulkan teman-taman dalam rangka latihan seni di Cireundeu karena sudah asyik dengan main handphone, meskipun ada batasan yang ditetapkan menggunakan HP, biasanya 4 jam sehari" (WR, 2021).

Selain smartphone fasilitas lain seperti televisi juga memberikan celah akan masuknya budaya luar yang bisa saja menggeser kultur dan kearifan lokal masyarakat kampung adat Sunda Wiwitan (Manullang, 2021). Dalam salah satu wawancara, diungkapkan secara gamblang bahwa:

"Saat ini tontonan yang ada di TV pun jarang yang menghadirkan edukasi terkait 
adat dan budaya, malah banyaknya sinetron yang malah berpengaruh negatif." (KY, 2021).

Lebih lugas KY sangat khawatir bukan hanya budaya Sunda Wiwitan akan luntur, akan tetapi kehadiran teknologi yang berpotensi melunturkan etika masyarakat adat itu sendiri jika mereka tidak berhasil mengatur dan mengontrolnya. Berdasarkan pernyataan tersebut meberikan gambaran bahwa teknologi menjadi salah satu tantangan terbesar bagi kehadiran nilai-nilai dan etika berinteraksi masyarakat (Listari, 2021). Namun, sudat pandang yang berbeda disampaikan oleh AW, salah satus sesepuh kampung adat Cireundeu yang cenderung lebih optimistis memandang keterbukaan interaksi dengan dunia luar. Bahkan menurutnya, keterbukaan yang dihadapkan oleh masyarakat adat merupakan sebuah pengalaman.

"Hal (keterbukaan) seperti itu dianggap menjadi sebuah pengalaman, karena masyarakat adat yang keluar dari lingkungan adat berarti sudah siap menghadapi apa yang dihadapi" (AW, 2021).

Selain dari internal kampung adat, pemerintah notabennya unsur ekternal kampung adat memberikan penguatan akan keberadaan kampung adat Sunda Wiwitan, sehingga status sebagai kampung wisata dianggap berpeluang untuk menjadi ikon pemerintah kota. Pemerintah kota oun memberikan dukungan penuh akan kemajuan kampung adat sebagai destinasi wisata, sebagaimana yang diampaikan oleh AR yang merupakan Analis Kebudayaan Disbudparpora Kota Cimahi bahwa:

"Pemerintah kota pun terus berupaya dan memiliki keinginan bagaimana caranya untuk membuat destinasi wisata untuk yang buatan ataupun yang baru, sehingga ditunjang oleh pemerintah kota ataupun dari kementerian atas rekomendasi pemerintah kota dari segi fasilitasnya, pembinaan SDM, pembinaan Masyarakat Adatnya hampir setiap tahun ada pembinaan" (AR, 2021).

Kampung adat Cireundeu sampai saat ini belum memenuhi syarat untuk sepenuhnya dinyatakan sebagai kampung adat dengan demikian kampung tersebut belum memiliki surat keputusan secara formal. Selain itu keberdaaan Kampung Adat Cireundeu belum lama seperti suku Baduy, dan masyarakat di Cireundeu ini hanya merupakan keturunan dari Kampung Adat Cigugur yang ada di Kuningan.

Masyarakat adat di Cireundeu sangat mengedepankan pendidikan untuk anakanaknya sehingga banyak sekali pemuda yang bersekolah di luar daerah mereka tinggal karena keterbatasan sekolah yang ada di daerah tersebut. Hal tersebut sangat memungkinkan nilai-nilai baru masuk dan baru diketahui oleh para pemudanya sehingga ada kekhawatiran tradisi leluhur akan luntur. Namun, IE sebagai salah satu masyarakat adat dengan profesi PNS memiliki keoptimisan terhadap para pemuda yang bersekolah ke luar daerah tempat tinggalnya tetap memegang teguh jati diri mereka sebagai masyarakat adat karena didikan orang tua terhadap anaknya sehingga adat serta budaya akan selalu lestari. Selain itu, KY juga mengungkapkan bahwa:

"Sebagai orang tua harus bisa mendidik terkait adat dan budaya anak kita dari rumah, karena segala sesuatu itu awalnya berasal dari pendidikan dari rumah." (KY, 2021).

Kekhawatiran lainnya adalah perihal diskriminasi yang akan terjadi pada anak-anak mereka seperti yang mereka alami dulu semasa mereka masih duduk di bangku sekolah. Namun IE menyampaikan bahwa:

"Saat ini masyarakat adat terutama pemudanya sudah mau menunjukkan jati dirinya di hadapan masyarakat lain. Diskriminasi yang muncul terhadap masyarakat adat mengenai agama sudah mulai luntur, karena sudah adanya pengakuan agama pada komunitas adat yang terdapat pada Putusan Mahkamah Konstitusi No. 97/PUU-XIV/2016. Dengan adanya putusan MK ini, masyarakat adat merasa lebih terlindungi” (IE, 2021).

Keberadaan putusan Mahkamah
Konstitusi No. 97/PUU-XIV/2016
memberikan ruang baru akan eksistensi
mereka sebagai penganut agama lokal dan
mendapat kebebasan penuh dalam
menjalankan aktivitas mereka. Secara
eksplisit berbagai tantangan dihadapi oleh
masyarakat adat di Kampung wisata Cirendeu
baik yang bersumber dari internal maupun
eksternal masyarakat adat di era post truth.




\section{c. Keseharian Komunitas Sunda Wiwitan di Kampung Wisata}

Kampung Adat Cireundeu merupakan desa adat yang terletak di lembah Gunung Kunci, Gunung Cimenteng dan Gunung Gajahlangu, namun secara administratif berada di Kelurahan Leuwigajah, Kecamatan Cimahi Selatan, Kota Cimahi. Kampung Adat Cireundeu dikelola oleh Dinas Koperasi, UMKM, Perindustrian, dan Pertanian (DISKOPINDAGTAN) yang membawahi Seksi Pariwisata dan Kebudayaan Kota Cimahi. Masyarakat Kampung Adat Cireundeu yang dipimpin oleh ketua adat terbagi menjadi tiga bagian, yaitu:

\section{Sesepuh atau Ketua Adat}

Tugas sesepuh atau pemimpin adat ini adalah membingbing dan memelihara tradisi yang diwariskan, memimpin ritual adat, dan bertindak sebagai pemegang hukum tertinggi untuk menentukan keputusan adat.

\section{Ais Pangampih atau Penerima Tamu}

Tugas ais pangampih adalah membantu sesepuh dalam menjalankan tugasnya serta mengatur sistem peradaban atau sosial budaya dari dulu hingga sekarang.

\section{Panitren atau Humas}

Tugas dari panitren adalah berperan sebagai pengamat, peneliti dan mengawasi kehidupan warga desa di Kampung Cireundeu.

Dari struktur pengelolaan yang dimiliki oleh Kampung Adat Cireundeu dapat diketahui bahwa statusnya sebagai kampung wisata tidak dapat diragukan lagi. Pemerintah Daerah Kota Cimahi melalui Dinas Pariwisata membentuk Kelompok Penggerak Pariwisata (Kompepar) di Kampung Adat Cireundeu dengan tujuan untuk kegiatan pariwisata. Ketika wisatawan datang berkunjung untuk tujuan pariwisata, maka para wisatawan akan dipersilakan masuk dan diterima di Balé Saréséhan lalu akan ada pemaparan mengenai Cireundeu dan sejarahnya.

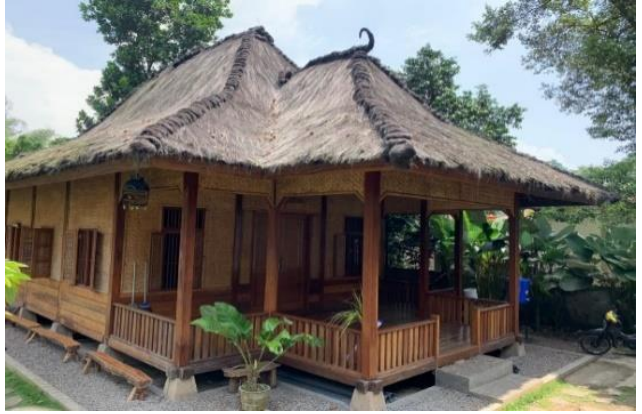

Gambar 2. Balé Saréséhan

Selanjutnya, para wisatawan akan dibawa untuk ke hutan yang sudah dijelaskan sebelumnya, akan tetapi para wisatawan tidak bisa memasuki leweung larangan, hanya bisa masuk ke leweung baladahan saja. Setelah selesai dari hutan, para wisatawan akan dibawa ke tempat pembuatan rasi (beras singkong). Rasi yang sudah jadi akan diolah oleh UMKM yang dimiliki oleh masyarakat adat dengan jumlah $15-20$ orang. Rasi yang ada akan diolah menjadi kue-kue dengan izin Pangan Industri Rumah Tangga (PIRT) sejumlah 12 jenis, seperti egg roll dan dendeng kulit singkong yang banyak diminati oleh para wisatawan, kue semprong, kicipir, cireng, lidah kucing, dan sebagainya.

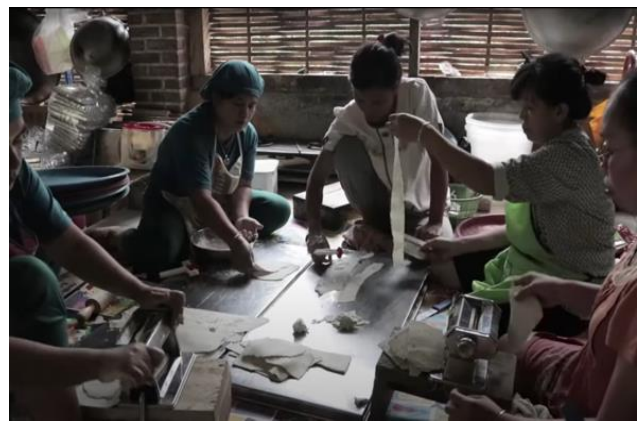

Gambar 3. Proses Pengolahan Rasi

Untuk wisatawan anak-anak biasanya dibawa untuk bermain permainan tradisional, seperti hahayaman, oray-orayan, perepet jengkol. Selain itu, ada juga permainan yang khusus memakai alat seperti lodong, papanahan, egrang, juga membuat kreativitas dengan menggunakan janur dan pelepah daun singkong yang biasanya dibuat gelang, kalung dan wayang. Selepas runtutan kegiatan di atas, maka kegiatan wisata di Kampung Adat Cireundeu selesai. Dengan dibentuknya Kompepar, masyarakat adat yang ada di Kampung Cireundeu berharap bahwa kesenian, kebudayaan, adat-istiadat yang ada di Cireundeu akan semakin kuat dan maju. 


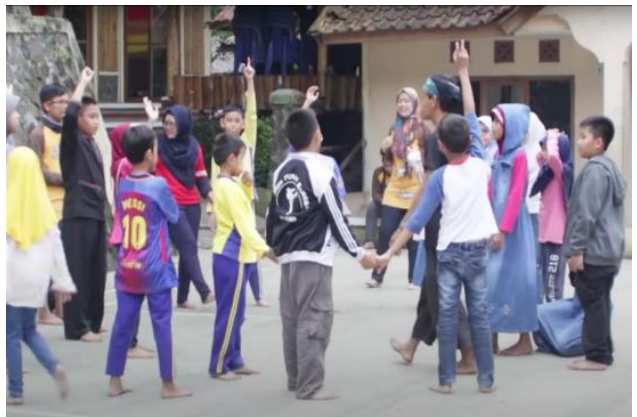

Gambar 4. Permainan Tradisional

Sebelum adanya Covid-19, para wisatawan diperbolehkan untuk menginap di sana. Penginapan yang disediakan oleh masyarakat adat sendiri bukanlah dalam bentuk hotel atau cottage, akan tetapi rumah dari masyarakat adat tersendiri. Statusnya sebagai kampung wisata memberikan nilai plus tersendiri bagi Kota Cimahi, di samping menambah Pendapatan Asli Daerah (PAD) Kota Cimahi melalui wisatawan yang berkunjung ke Kampung Adat Cireundeu juga menjadi sarana bagi Pemerintah Daerah (Pemda) Kota Cimahi untuk memperkenalkan salah satu adat dan budaya yang ada di Indonesia.

Aktivitas sehari-hari yang dilakukan oleh masyarakat adat di Kampung Adat Cireundeu tidak jauh berbeda dengan aktivitas yang dilakukan oleh masyarakat biasa. Profesi masyarakat adat di Kampung Cireundeu cukup beragam, dengan komposisi $80 \%$ petani dan peternak serta $20 \%$ lainnya berprofesi sebagai buruh pabrik, buruh bangunan, harian lepas, pemilik warung jajanan, guru, dan lain-lain. Selain aktivitasnya, pakaian yang dipakai oleh masyarakat adat pun seperti masyarakat biasa. Namun, mereka juga memiliki baju adat, yakni pangsi untuk laki-laki dan kebaya untuk perempuan.

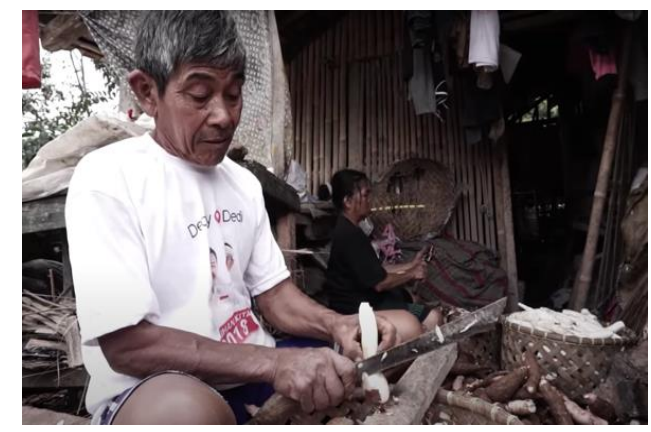

Gambar 5. Petani Ketela
Meskipun kehidupannya menyatu dengan masyarakat dengan kepercayaan lain, namun ritual atau tradisi masyarakat adat tetap mereka jalankan. Masing-masing pihak memiliki toleransi yang sangat tinggi. Mereka memegang teguh pepatah Sunda yang mengatakan bahwa, "ulah poho kana kulah getih sorangan" yang artinya jalan lupa akan tanah kelahiran atau ibu pertiwi, serta sebuah ungkapan yang mengingatkan merekan akan sebuah hak dan yang bukan, yaitu "budaya batur dimumule, budaya sorangan dipohokeun cul dogdog tinggal igel" yang artinya budaya bangsa lain dipelihara, sementara budaya bangsa sendiri dilupakan.

Terdapat beberapa praktik yang dijalankan oleh masyarakat adat yang penulis bagi ke dalam tiga bagian, yaitu tradisi/ritual, kesenian, dan sosial. Ada beberapa tradisi/ritual yang dijalankan oleh masyarakat adat, di antaranya:

\section{Upacara Adat 1 Sura}

Peringatan atau upacara adat 1 (satu) Sura sesuai kalender Saka Sunda. Upacara atau ritual ini merupakan hari besar atau lebaran umat pemeluk aliran kepercayaan. Biasanya dilakukan mulai dari pagi hari hingga malam hari yang bertempat di Bale (tempat berkumpul masyarakat adat), bale sendiri memiliki arsitektur yang mempunyai arti khusus. Pertama, bentuk atap yang lurus ke atas yang berarti masyarakat Cireundeu memiliki satu tujuan kepada Tuhan. Di Kampung Adat Cireundeu sendiri masyarakatnya bersifat terbuka terhadap agama atau kepercayaan selain yang mereka anut, mereka memandang perbedaan terutama dalam hal kepercayaan adalah sesuatu keindahan. Kedua, terdapat empat helai kain dengan warna yang berbeda yang mengandung arti unsur-unsur bumi, terdiri dari warna hitam mempunyai makna "bumi", warna kuning bermakna "angin", warna putih "air", dan yang terakhir merah bermakna api.

Selain itu, ritual yang sangat mereka sakralkan pada tanggal 1 (satu) Sura masih tetap mereka jalankan dengan baik dengan makna untuk mensyukuri nikmat yang telah diberikan Sang Pencipta selama ini kepada masyarakat Cireundeu. AW menyatakan bahwa: 
"Walau banyak secara penglihatan mengalami banyak perubahan, namun tradisi adat selalu ada di dalam hati" (AW, 2021).

"Jika terdapat kegiatan atau perayaan besar yang diadakan oleh masyarakat adat warga sekitar akan gotong-royong saling membantu satu sama lain tanpa melihat agama dan dari mana asalnya" (AW, 2021)

Merujuk pada pernyataan-pernyataan yang disampaikan oleh AW selaku salah satu sesepuh kampung adat menggambarkan bahwa ritual yang disakralkan oleh masyarakat adat tidak mendapatkan sentimen negatif dari masyarakat non adat, termasuk perayaan 1 Sura.

Makna upacara 1 Sura bagi masyarakat adalah untuk mensyukuri nikmat yang telah diberikan Sang Pencipta selama ini kepada masyarakat Cireundeu. 1 Sura bagi warga Cireundeu, ibarat Lebaran. Sebelum tahun 2000-an, mereka selalu mengenakan pakaian baru. Namun beberapa tahun terakhir ini, adat mereka dilembagakan. Saat upacara adat, kaum lelaki mengenakan pakaian pangsi warna hitam, sementara kaum perempuan mengenakan kebaya atau pakaian warna putih. Gunungan sesajen, berupa buah-buahan dan nasi singkong, tersaji di tengah reriungan warga di Balai Adat.

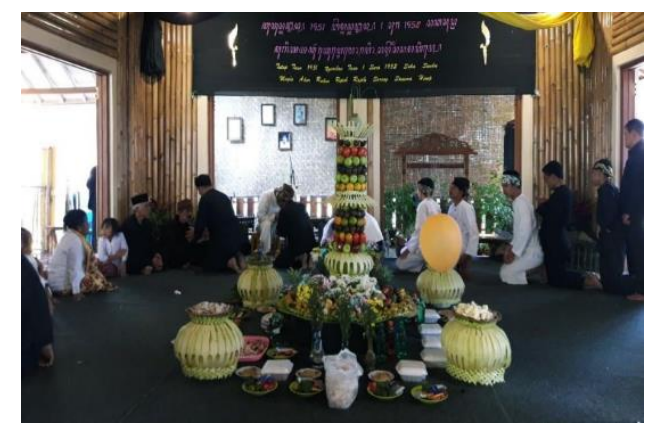

Gambar 6. Upacara Adat 1 Sura

\section{Ritual Pernikahan}

Selain upacara 1 Sura, terdapat juga ritual pernikahan adat yang tetap dijalankan. Ritual adat dalam pernikahannya terdiri dari ngaras, sungkeman, ngeuyeuk seureuh, dan ikrar jatukrami. Pernikahan adat ini diawali oleh upacara pangbagea atau upacara pangbage untuk pengantin yang di dalamnya terdapat lengser, payung, umbul-umbul, dan tari pamayang. Setelah itu dilanjutkan dengan seren tampi dan sawer. Lalu dilanjutkan dengan turun bantayan dan huap lingkung.
Karena makanan masyarakat adat dengan yang lain itu berbeda, akan tetapi jika dalam acara pernikahan adat tetap disediakan 2 jenis nasi, yaitu nasi singkong dan nasi beras.

Kedua, ada praktik kesenian yang senantiasa dilestarikan oleh masyarakat adat. Beberapa alat kesenian yang sering di ajarkan kepada anak-anak di sana, di antaranya kecapi suling, karinding, degung, angklung buncis, dan lain-lain. Masyarakat adat sering diundang untuk mengisi kegiatan seni di luar daerah. Salah satu alat kesenian yang regenerasinya diakui sangat bagus oleh masyarakat luar adalah angklung buncis. Kang Yadi mengungkapkan bahwa

"Perbedaan antara angklung daeng/ angklung biasa dengan angklung buncis yaitu secara nada berbeda angklung daeng diatonis angklung buncis pentatonis, namun dari fisik tidak jauh berbeda tapi dapat dibedakan dari kayunya yang lebih gelap." (KY, 2021)

Selain diajarkan alat seninya, anak-anak di sana juga diajarkan makna filosofisnya dari masing-masing alat seni, contohnya untuk angklung buncis KY menyatakan:

"Angklung sendiri punya makna filosofis seperti yang dikatakan orang tua zaman dahulu, bahwa angklung menggambarkan seperti kita hidup di hamparan tanah yang luas (tabung dasar) seperti bumi dan di alam dunia kita memiliki pasangan yang terdiri dari 2 (tabung besar dan tabung kecil) dan 3 ketentuan yang digambarkan pada 3 rangka yang menjulang, 3 ketentuan itu adalah tri tangtu di na raga, tri tangtu di nagara, jeung tri tangtu di buana." (KY, 2021)

Ketiga, ada praktik sosial yang senantiasa mereka jalankan dan harus dilakukan sebagai makhluk sosial sebagaimana mestinya. Seperti, saur kudu dibubut yang memiliki arti bahwa jika bercerita atau berbicara harus hatihati dan harus pada tempat yang sesuai. Basa kedah dihampelas yang memiliki arti bahwa berbicara itu harus dengan baik dan sopan. Gotong royong yang merupakan sebuah kegiatan sosial kemasyarakatan dengan tujuan untuk saling membantu meringankan beban pekerjaan sesama (Bagas \& Radjab, 2019). Keempat, toleransi agama. Hal terakhir ini merupakan salah satu kunci mengapa masyarakat adat Cireundeu dapat hidup berdampingan secara harmonis dengan 
masyarakat sekitar, karena mereka memiliki toleransi agama yang sangat tinggi.

Studi ini memperlihatkan bagaimana Sunda Wiwitan sebagai komunitas lokal dan kampungnya dinyatakan sebagai daerah wisata harus mengalami penyesuaian dengan dunia luar dan berbagai tantangan yang dihadapi dalam upaya mempertahankan diri. Tantangan yang ada berasal dari dua arah; internal dan eksternal kampung adat. Di internal kampung adat, masyarakat telah membuka diri dengan berbagai produk modernisasi dan teknologi (Inawati, 2014) yang memungkinkan mereka menerima nilainilai baru. Hal ini berdampak pada komitmen untuk menjaga orisinalitas adat mengalami ancaman karena menurunnya konsentrasi pada pewarisan nilai adat berbasis internalisasi melalui proses adat. Sementara itu, ancaman dari eksternal berupa status kampung wisata yang telah ditetapkan oleh pemerintah daerah. Namun disisi lain negosiasi dengan status sebagai kampung wisata mampu menjadi memediasi (Nusanto \& Widiyanto, 2021) berbagai kepentingan dari berbagai pihak termasuk kepentingan masyarakat adat yakni untuk memperoleh pengakuan dan keberadaannya tetap eksis.

Status kampung wisata memberikan atmosfer baru akan keterbukaan dengan dunia luar. namun dalam membendung hal tersebut, masyarakat adat harus menjunjung nilai "ngindung ka waktu, mibapa ka jaman" tetap menjaga tradisinya walau tidak terlihat dengan banyaknya perubahan di kampung adat, tradisi tetap dijaga dan tidak boleh dihilangkan untuk mengisi keindahan negara yang berasal dari ragam budaya yang ada walau tidak mudah dalam menjaga budaya adat karena adanya arus globalisasi. Namun demikian, tantangan yang dihadapi membuat masyarakat adat untuk tetap berpegang teguh pada ajaran dan nilai leluhur khususnya pemuda sebagai generasi penerus. Motto hidup orang Ssunda "welas asih, yaitu "silih asah silih asih silih asuh" (Fauzia, Maslihah, \& Wyandini, 2020). Pepatah tersebut menggambarkan sebuah wujud ajaran kepedulian dan simpati. Dalam hal ini, peduli dan simpati terhadap sesama yang senantiasa harus dijaga sehingga ketika orang luar datang ke Cireundeu tidak terjadi aksi diskriminatif (Jena, 2014).
Meskipun demikian, dengan keterbukaan mereka terhadap dunia luar, selain memberikan peluang untuk dapat menyebarkan informasi mengenai ketahanan pangan mereka, juga banyak kekhawatirankekhawatiran yang masih masyarakat adat pikirkan. Banyak harapan yang mereka simpan bagi penerus mereka, yaitu para putra dan putri, putu dan yang lainnya untuk kebiasaan tidak memakan nasi dari jenis padipadian dan hanya memakan rasi bisa bertahan seterusnya dan pemerintah dapat menjadikan hal ini sebagai pilot project percontohan ketahanan pangan nasional. Hal ini menegaskan bahwa masyarkat adat memiliki mekanisme untuk selalu menjaga kestabilan dan ketercukupan bahan makanan pokoknya. Ini juga merupakan cara untuk menjaga keberlangsungannya di masa mendatang.

Keberlangsungan Sunda Wiwitan dengan keberadaannya berada dalam kampung adat dan statusnya sebagai destinasi wisata membutuhkan upaya penguatan nilai-nilai luhur pada pada masyarakat adat karena sesungguhnya nilai-nilai tersebut dapat menjadi instrumen atau alat untuk menguatkan keberadaan dan membantu mereka beradaptasi dengan kondisi dan lingkungan yang ada (Jubba, Pabbajah, Prasodjo, \& Qodir, 2019). Beberapa strategi bertahan yang dilakukan oleh masyarakat adat di Kampung Cireundeu untuk mempertahankan, adat istiadat, budaya dan kesenian di tengah keterbukaan mereka adalah dengan cara Pertama, Orang tua tetap mengajarkan ajaran leluhur agar anak-anak mereka tetap kokoh dan teguh pendirian sebagai penghayat. Ajaran leluhur dintegrasikan pada nilai-nilai yang masuk dan berkembang ditengah masyarakat. Cara tersebut diterapkan untuk mempertahankan tradisi dan ajaran leluhur (Agiati, 2017) Kedua, Setiap malam sabtu diadakan latihan kecapi serta seni lain bagi anak-anak. Ketiga, Setiap sabtu siang ada pendidikan agama untuk masyarakat adat dan juga pembelajaran aksara sunda serta pendekatan personal maupun kelompok tentang kehidupan dan aktivitas sehari-hari dari sesepuh adat kepada generasi penerus di Kampung Cireundeu.

Secara umum, bentuk kegiatan yang dilakukan merupakan wujud negosiasi nilai ajaran agama dan leluhur dimana nilai tersebut dijadikan dasar untuk menguatkan 
eksistensi mereka. Masyarakat lokal mampu bertahan dengan cara negosiasi dan resistensi (Ismail, 2015). Komitmen masyarakat lokal untuk terus menjaga tradisi yang diwarisinya memiliki fungsi tidak saja sebagai kohesi sosial di internal kelompok, tetapi juga sebagai media komunikasi dengan kelompokkelompok sosial di luar termasuk pemerintah. Identitas lokal yang disandang tidak menjadikannya terpinggirkan karena memiliki sejumlah entitas yang dapat dijadikan komoditas untuk kepentingan yang beragam. Dalam konteks masyarakat adat di Cireundeu, setelah ditetapkan sebagai masyarakat adat dan menjadi bagian dari pariwisata oleh pemerintah, maka kondisinya berubah dan lebih terbuka sehingga memungkinkan terjadi akomodasi-akomodasi yang bertujuan untuk menjamin keberlangsungan kelompok di satu sisi, dan mengakomodasi keberadaannya sebagai bagian dari kelompok yang dikomersailkan di sisi lain.

\section{Kesimpulan}

Ternyata hubungan agama lokal, kultur dan teknologi akan selalu menarik dan memiliki sisi untuk dikaji dari berbagai sudut pandang dan pendekatan. Temuan kunci penting dalam penelitian ini adalah adanya hubungan kuat antara teknologi, kultur atau kearifan lokal yang menjadi daya tarik wisata di kampung adat Sunda Wiwitan serta bagaimana masyarakat adat mampu beradaptasi dengan segala keterbukaan yang ada. Secara ringkas, ada tiga temuan dalam studi ini. Pertama, status Kampung Adat Cireundeu sebagai kampung wisata dengan segala keterbukaan membuat masuknya teknologi sulit untuk dibendung menjadi sebuah tantangan terbesar yang dapat mengancam keberlangsungan Sunda Wiwitan.

Kedua, pemerintah memberikan perhatian dalam peningkatan kualitas dan nilai sebagai status destinasi wisata yang melekat pada kampung adat Cireundeu agar mampu meningkatkan PAD.Wujud upaya pemerintah dalam menacapai hal tersebut dengan menobatan Kampung adat Cirendeu sebagai daerah yang dapat dijadikan role model ketahanan pangan nasional, kekonsistenan masyarakat mengkonsumsi Rasi sebagai makanan utama pengganti nasi dan padipadian menjadi identitas yang sudah melekat pada masyarakat adat Kampung Cirendeu. Selain itu, pemerintah memberikan kontrol dan pembinaan secara khusus melalui Dinas Koperasi, UMKM, Perindustrian, dan Pertanian (DISKOPINDAGTAN) Kota Cimahi.

Ketiga, ajaran Sunda Wiwitan yang telah turun temurun ditanamkan ke masyarakat adat mampu menjadi pijakan dan tameng untuk menghadapi keterbukaan dan arus globalisasi. Ajaran "ngindung $k a$ waktu, mibapa $k a$ jaman" yang selalu dijunjung oleh masyarakat Adat merefresentasikan bahwa bagaimana mereka menghadapi segala bentuk keterbukaan yang ada. Hal tersebut menjadi bentuk negosiasi dan kompromi masyarakat adat tanpa melakukan penolakan secara brutal terhadap arus dunia globalisasi, karena tidak dapat dipungkiri bahwa teknologi telah menjadi bagian yang sulit untuk dipisahkan dalam kehidupan masyarakat termasuk masyarakat adat Kampung Cirendeu.

Sumbangsih yang dapat diperoleh dari studi ini, menjadi bahan pertimbangan dan referensi bagi pemerintah daerah dalam mengambil kebijakan yang berhubungan dengan komunitas adat yang status sebagai destinasi wisata. Secara khusus keberadaan studi ini diharapkan mampu menggambarkan kondisi Sunda Wiwitan di era modern sehingga menumbuhkan kepedulian dari berbagai pihak termasuk generasi muda Sunda Wiwitan. Keterbatasan penelitian terbatas hanya pada satu kelompok, jumlah informan relatif sedikit dan waktu penelitian cukup singkat, sehingga tidak dapat dijadikan sebagai standar generalisasi yang lebih mendalam dan komprehensif.

\section{Daftar Pustaka}

Agiati, R. E. (2017). Adaptasi Komunitas Adat Kampung Kuta Terhadap Lingkungan Sosialnya di Kabupaten Ciamis. Peksos: Jurnal Ilmiah Pekerjaan Sosial, 16(2). https://doi.org/10.31595/peksos.v16i 2.118

AR. (2021). Wawancara.

AW. (2021). Wawancara.

Bagas, \& Radjab, M. (2019). Tergerusnya Gotong Royong di Desa Tadang Palie Kecamatan Ulaweng Kabupaten Bone. Hasanuddin Journal Of 
Sociology, 1(2). Diambil dari https://journal.unhas.ac.id/index.php/ HJS/article/view/9431

Budijanto, O. W. (2016). Penghormatan Hak Asasi Manusia Bagi Penghayat Kepercayaan di Kota Bandung. Jurnal HAM, 7(1), 35-44. https://doi.org/10.30641/ham.2016.7. 35-44

Dahlan, M., \& Liemanto, A. (2017). Perlindungan Hukum Atas Hak Konstitusional Para Penganut Agama-Agama Lokal di Indonesia. Arena Hukum, 10(1), 20-39. https://doi.org/10.21776/ub.arenahuk um.2017.01001.2

Dudi, J. (2018). Faktor Pendukung dan Penghambat Perkembangan Agama Lokal Kaharingan pada Etnis Dayak. Jurnal Mediasosian: Jurnal Ilmu Sosial dan Administrasi Negara, 2(2). https://doi.org/10.30737/mediasosian .v2i2.211

Fajarini, U. (2021). Dampak Teknologi Modern Terhadap Kearifan Lokal Sebagai Kelestarian Lingkungan Alam Dan Ketahanan Pangan Di Indonesia Studi Kasus Kampung Adat Cireundeu Jawa Barat. SOSIODIDAKTIKA: Social Science Education Journal, 7(2), 336-363.

Farakhiyah, R., \& Irfan, M. (2019). Eksistensi Masyarakat Adat Tergerus Oleh Kebutuhan Zaman Studi Analisis Konflik Masyarakat Adat Sunda Wiwitan di Kuningan yang Terusir dari Tanah Adatnya Sendiri dengan Teori Identitas. Jurnal Kolaborasi Resolusi Konflik, 1(1), 44-54. https://doi.org/10.24198/jkrk.v1i1.20 892

Fauzia, N., Maslihah, S., \& Wyandini, D. Z. (2020). Trisilas Local Wisdom Scale, Silih Asih, Silih Asah, Silih Asuh. Jurnal Psikologi TALENTA, 5(2), 121-126.

https://doi.org/10.26858/talenta.v5i2. 12757

Fringka, Y. (2016). Resistensi Berbasis Adat: Perlawanan Masyarakat Nagari III Koto, Tanah Datar, Sumatera Barat, terhadap Rencana Tambang Bukit Batubasi. MASYARAKAT: Jurnal Sosiologi, 21(2), 205-231. https://doi.org/10.7454/mjs.v21i2.46 70

Gunawiayu, A., Purnomowulan, N. R., \& Wardiani, S. Ri. (2019). Resistensi dan Negosiasi Peran Perempuan Dalam Roman Medea. Stimmen Karya Christa Wolf. Metahumaniora, 9(2), 276-290. https://doi.org/10.24198/metahumani ora.v9i2.22673

IE. (2021). Wawancara.

Inawati, A. (2014). Peran Perempuan Dalam Mempertahankan Kebudayaan Jawa dan Kearifan Lokal. Musãwa Jurnal Studi Gender Dan Islam, 13(2), 195206.

https://doi.org/10.14421/musawa.201 4.132.195-206

Ismail, N. (2015). Strategi Bertahan Kelompok Agama Lokal. Harmoni, 14(3), 114-128.

Jena, Y. (2014). Etika Kepedulian: Welas Asih Dalam Tindakan Moral. Kanz Philosophia, 4, 1-14. https://doi.org/10.20871/kpjipm.v4i1. 51

Jubba, H., Pabbajah, M., Prasodjo, Z. H., \& Qodir, Z. (2019). The future relations between the majority and minority religious groups, viewed from indonesian contemporary perspective: A case study of the coexistence of Muslims and the Towani Tolotang in Amparita, South Sulawesi. International Journal of Islamic Thought ( IJIT ), 16, 13-23.

KY. (2021). Wawancara.

Listari, L. (2021). Dekadensi Moral Remaja (Upaya Pembinaan Moral Oleh Keluarga dan Sekolah). Jurnal Pendidikan Sosiologi Dan Humaniora, 12(1), 7-12. https://doi.org/10.26418/jpsh.v12i1.46320

Manullang, S. O. (2021). Perubahan Sosial Masyarakat Pedesaan di Era Teknologi. Cross-Border, 4(1), 8388.

Muhammad, N. (2017). Resistensi Masyarakat Urban Dan Masyarakat Tradisional Dalam Menyikapi Perubahan Sosial. Substantia: Jurnal Ilmu-Ilmu Ushuluddin, 19(2), 149168. 
https://doi.org/10.22373/substantia.v 19i2.2882

Nurhayanto, P., \& Wildan, D. (2016). Transformasi Nilai-Nilai Kearifan Lokal Masyarakat Adat Cireundeu. SOSIETAS, 6(1). https://doi.org/10.17509/sosietas.v6i 1.2872

Nusanto, T. S., \& Widiyanto, N. (2021). Eksistensi Adat, Tanah Ulayat dan Pariwisata di Kasepuhan Ciptagelar, Jawa Barat. Pariwisata Budaya: Jurnal Ilmiah Agama Dan Budaya, 6(1), 37-47.

Pamungkas, C. (2014). Toleransi Beragama Dalam Praktik Sosial: Studi Kasus Hubungan Mayoritas dan Minoritas Agama di Kabupaten Buleleng. Epistemé: Jurnal Pengembangan Ilmu Keislaman, 9(2), 285-316. https://doi.org/10.21274/epis.2014.9. 2.285-316

Rahmawati, S., Al-Uswah, H., B, S. A., Mubriqoh, L. A., Mutia, D. H., Musyafaq, M., ... Wafidhi, A. (2019). Tradisi Tirakatan di Ngoro-Oro: Analisis Budaya Masyarakat menurut Perspektif Badawa Ibnu Khaldun dan Solidaritas Emile Durkheim. Prosiding Konferensi Pengabdian Masyarakat, 1, 451-454.

Retalia, R. (2020). Dampak Intensitas Penggunaan Smartphone Terhadap Interaksi Sosial. EduPsyCouns: Journal of Education, Psychology and Counseling, 2(2), 45-55.

Risyadah, E. (2021). Optimalisasi Potensi Hadapi Pandemi. Bandung: LP2M UIN SGD Bandung.

Sabandiah, R. N., \& Wijaya, E. (2018). Diskriminasi terhadap Agama Tradisional Masyarakat Hukum Adat Cigugur. Jurnal Penelitian Hukum De Jure, $\quad$ 18(3), 335-352. https://doi.org/10.30641/dejure.2018. V18.335-352

Salim, M. (2016). Adat Sebagai Budaya Kearifan Lokal Untuk Memperkuat Eksistensi Adat ke Depan. Al Daulah: Jurnal Hukum Pidana Dan Ketatanegaraan, 5(2), 244-255. https://doi.org/10.24252/ad.v5i2.484 5

Santi, K. (2021, Juni 11). Perubahan Sosial Budaya Masyarakat Akibat dari Kemajuan Ilmu Pengetahuan dan Teknologi di Dusun Batukol Kabupaten Barito Selatan. OSF Preprints. https://doi.org/10.31219/osf.io/gtfre

Sukirno, S. (2018). Diskriminasi Pemenuhan Hak Sipil Bagi Penganut Agama Lokal. Administrative Law and Governance Journal, 1(3), 231-239. https://doi.org/10.14710/alj.v1i3.231239

Vonika, N. (2020). Pemenuhan Hak Sipil Dalam Konteks Kesejahteraan Sosial Bagi Masyarakat Adat Sunda Wiwitan Kampung Cireundeu. Peksos: Jurnal Ilmiah Pekerjaan Sosial, 19(1). https://doi.org/10.31595/peksos.v19i 1.252

Wahyuni, D. (2019). Resistensi Masyarakat Petalangan Mempertahankan Kearifan Lokal dalam "Kemantan Muda Roh Belian". Bahasa: Jurnal Keilmuan Pendidikan Bahasa dan Sastra Indonesia, 1, 1-18. https://doi.org/10.26499/bahasa.v1i1. 21

WR. (2021). Wawancara. 